\title{
Efektivitas Bunga Wijaya Kusuma (Epiphyllum oxypetalum) Terhadap Penurunan Kadar Asam Urat Tikus Wistar
}

\author{
Ni Putu Rahayu Artini ${ }^{1)}$, I Wayan Tanjung Aryasa ${ }^{1)}$ \\ Program Studi Teknologi Laboratorium Medik \\ Institut Ilmu Kesehatan Medika Persada Bali \\ Email : artinirahayu967@gmail.com
}

\begin{abstract}
Tanggal Submit:

28 Januari 2019

Tanggal Review:

30 April 2019

Tanggal Publish

Online:

19 September 2019

The isolation of wijaya kusuma (Epiphyllum oxypetalum) flower was carried out in this study. Methanol was applied to maceration an $27 \mathrm{~g}$ sample of extract its was produced from $250 \mathrm{~g}$ of sample powder. In vivo test results, methanol extract of wijaya kusuma flower (Epiphyllum oxypetalum) dose of $100 \mathrm{mg} / \mathrm{kg} \mathrm{BB}, 200 \mathrm{mg} / \mathrm{kg} \mathrm{BB}$, and $400 \mathrm{mg} / \mathrm{kg}$ BW can decreasing uric acid concentration. From this research, it was obtained that the best dose of extract of wijaya kusuma flower (Epiphyllum oxypetalum) applied to decrease uric acid was $400 \mathrm{mg} / \mathrm{Kg}$ BW with a decrease percentage of $63,50 \%$. The probit test results obtained the value of ED50 methanol extract of wijaya kusuma flower (Epiphyllum oxypetalum) of $221 \mathrm{mg} / \mathrm{Kg}$ BB. In this study it can be concluded that soursop leaf extract (Annona muricata L.) can reduce uric acid levels in research mice. For future research, this method could be applied to human in decreasing uric acid concentration in blood.

Keywords: Kusuma Wijaya Flower (Epiphyllum oxypetalum), Extraction, Maceration, And Uric Acid.
\end{abstract}

\section{PENDAHULUAN}

\begin{tabular}{lcr}
\multicolumn{3}{c}{ Pesatnya perkembangan ilmu } \\
pengetahuan dan teknologi & serta \\
berubahnya & pola hidup masyarakat \\
berdampak & munculnya & berbagai \\
penyakit & degeneratif & yang
\end{tabular}
membahayakan. Asam urat merupakan salah satu dari beberapa penyakit yang sangat membahayakan karena bukan hanya mengganggu kesehatan tetapi juga dapat mengakibatkan cacat pada fisik.

Penyakit ini juga berkaitan erat dengan ginjal karena ginjal merupakan suatu organ yang berfungsi sebagai tempat pembuangan asam urat yang berlebihan. Ketika ginjal tidak mempunyai kekuatan untuk membuang asam urat yang berlebihan, maka hal ini yang menjadi salah satu penyebab terbentuknya asam urat (Asaidi, 2010). 
Asam urat adalah sisa metabolisme zat purin yang berasal dari makanan yang yang mengandung protein, seperti jeroan, daging, kerang, kepiting, udang, melinjo, kacang-kacangan, bayam, durian, tape, alkohol, dan lain-lain serta hasil samping dari pemecahan sel dalam darah. Purin adalah zat yang terdapat dalam setiap bahan makanan yang berasal dari tubuh makhluk hidup. Dengan kata lain, dalam tubuh makhluk hidup terdapat zat purin yang berasal dari makanan (Saraswati, 2009).

Di dalam tubuh telah terdapat $85 \%$ senyawa purin untuk kebutuhan sehari-hari, ini berarti kebutuhan purin dari makanan hanya $15 \%$. Kadar asam urat yang normal dalam tubuh adalah 3,5-7 mg/dL untuk laki-laki dan 2,6-6 $\mathrm{mg} / \mathrm{dL}$ bagi wanita (Saraswati, 2009). Hasil survey kesehatan tahun 2005 menyebutkan, $10-20 \%$ pria dewasa dan wanita postmonopause mempunyai kadar asam urat darah lebih dari normal. Asam urat dihasilkan dari proses metabolisme utama nukleosida purin melalui basa purin hipoxanthin, xanthin, dan guanin (Saraswati, 2009). Apabila terjadi penyimpangan dalam proses ini, maka kadar asam urat akan meningkat, hal ini disebut sebagai kondisi hiperurisemia (Stryer, 2000).
Hiperurisemia dapat diatasi dengan menurunkan produksi asam urat. Allopurinol sebagai inhibitor spesifik dari enzim xanthin oksidase (XO) yang mengkatalisis oksidasi hipoxanthin menjadi xanthin dan asam urat, terbukti efektif dalam menurunkan kadar asam urat (Gaw et al, 1998). Obat ini memiliki efek samping terutama reaksi alergi kulit, nyeri kepala, serta kerusakan hati dan ginjal (Tjay dan Rahardja, 2002). Efek samping yang membahayakan dari obat modern mendorong manusia untuk mencari alternatif yang lebih baik dengan mengembangkan penggunaan obat tradisional untuk menangani berbagai macam penyakit degeneratif (Soedibyo, 1991).

Antioksidan alami mampu melindungi tubuh terhadap kerusakan yang disebabkan spesies oksigen reaktif, mampu menghambat terjadinya penyakit degeneratif serta mampu menghambat peroksidase lipid pada makanan. Meningkatnya minat untuk mendapatkan antioksidan alami terjadi beberapa tahun terakhir ini. Bunga Wijaya Kusuma (Epiphyllum oxypetalum) segar atau batang yang masih segar digunakan untuk mengatasi radang, luka dan bisul, dan pemakaian dalam untuk mengatasi batuk, 
antiradang, dll. Belum banyak yang mengetahui khasiat dari tanmanan ini. Bunga wijaya kusuma dikenal sebagai ratu malam, dikarenakan aktivitas mekarnya bunga ini hanya pada malam hari, sedangkan esok paginya disaat matahari telah terbit bungan ini langsung layu.

Beberapa orang percaya bahwa mengkonsumsi seduhan bunga wijaya kusuma, yaitu bunganya dikeringkan kemudian dikonsumsi dengan direbus kemudian airnya diminum dapat menghilangkan rasa sakit pada kepala, meredakan peradangan bagi yang memiliki serangan batuk atau asma. Bagian batangnya juga dapat digunakan sebagai obat luka dan menetralkan pembekuan darah, serta mengobati abses. Namun, belum banyak informasi yang dapat diperoleh tentang manfaat dari tanaman unga wijaya kusuma. Berdasarkan uji skrining fitokimia yang telah dilakukan, bunga wijaya kusuma mengandung beberapa metabolit sekunder seperti saponin,alkaloid, dan triterpenoid.

$$
\text { Selain itu, adanya }
$$

kecenderungan masyarakat mengkonsumsi bunga wijaya kusuma untuk mencegah dan mengobati asam urat adalah alasan mengangkat topik ini dan untuk mengetahui secara ilmiah dosis maupun kandungan senyawa dari bunga wijaya kusuma dalam menurunkan kadar asam urat darah. Oleh karena itu, pada penelitian ini akan dilakukan aplikasinya melalui penurunan kadar asam urat darah pada tikus wistar yang diinduksi makanan tinggi purin, yaitu jus hati ayam dan melinjo.

\section{METODE PENELITIAN}

\section{Rancangan Penelitian}

Penelitian ini menggunakan rancangan penelitian true experimental dengan rancangan posttest only control group design dengan sampel bunga wijaya kusuma (Epiphyllum oxypetalum) yang diekstraksi dengan metode maserasi. Dilakukan analisis bioaktivitas secara in vivo untuk mengetahui persentase penurunan kadar asam urat pada tikus wistar yang diinduksikan makanan tinggi purin.

\section{Alat dan Bahan Penelitian}

Sampel yang digunakan pada penelitian ini adalah bunga wijaya kusuma (Epiphyllum oxypetalum) yang diperoleh dari daerah sekitar Denpasar dan Badung, Bali. Sampel dikeringkan dengan cara diangin-anginkan dan tidak kontak langsung dengan sinar matahari. Proses pengeringan dilakukan hingga simplisia dengan kadar air kurang dari 
10\%. Bahan kimia yang digunakan pada penelitian ini yaitu $\mathrm{CH}_{3} \mathrm{OH}$ (p.a), akuades, allopurinol, melinjo, pakan standar tikus, reagen uric acid FS TBHBA, dan hati ayam mentah. Peralatan yang digunakan pada penelitian ini adalah pisau, blender, ayakan, aluminium foil, labu ukur, gelas beaker, gelas ukur, desikator, pipit volume, batang pengaduk, ball filler, kertas saring, alat sonde, dan spuit $1 \mathrm{cc}$. Peralatan yang dipergunakan pada penelitian ini adalah neraca analitik, centrifuge, pipette micro, vakum putar penguap (rotary vacum evaporator), dan seperangkat alat spektrofotometer UVVis.

\section{Prosedur Penelitian}

Penyiapan bahan

$\begin{array}{rrr}\text { Bunga } & \text { Wijaya } & \text { Kusuma } \\ \text { (Epiphyllum } & \text { oxypetalum) } & \text { yang }\end{array}$
dibersihan, dikeringkan, dan dipotong kecil-kecil di blender kemudian diayak sehingga menjadi serbuk berwarna coklat dan ditimbang dengan neraca analitik.

\section{Ekstraksi bunga wijaya kusuma}

Sebanyak \pm 250 gram serbuk wijaya kusuma (Epiphyllum oxypetalum) diekstraksi dengan cara maserasi menggunakan metanol sebanyak 2 × 24 jam, dimana setiap maserasi digunakan $\pm 500 \mathrm{~mL}$ metanol, kemudian disaring. Ekstrak metanol dipisahkan dari pelarutnya dengan menggunakan rotary vacum evaporator sehingga diperoleh ekstrak kental metanol. Ekstrak ini kemudian dimasukkan dalam desikator sehingga diperoleh ekstrak kering. Ampas yang diperoleh dimaserasi kembali dengan pelarut metanol sampai diperoleh filtrat bening yang diperkirakan senyawa aktif dalam serbuk wijaya kusuma telah habis.

\section{Penyiapan hewan uji}

Sebelum digunakan, sebanyak 24 ekor hewan yang diuji diadaptasikan selama 1 minggu dengan tujuan agar tikus jantan wistar dapat menyesuaikan diri dengan lingkungannya, sambil dilakukan kontrol kesehatan, berat badan dan penyeragaman makanan yang diberikan dengan pemberian pakan standar dan diberi air minum ad libitum sebelum penelitian selama satu minggu. Selanjutnya untuk mencapai kondisi hiperurisemia, tikus wistar diberikan melinjo 4 g/kg BB+ jus hati ayam mentah $50 \mathrm{~mL} / \mathrm{kg}$ BB secara ad libitum. Sedangkan kelompok perlakuan diberikan ekstrak wijaya kusuma (Epiphyllum oxypetalum) dengan dosis $100 \mathrm{mg} / \mathrm{kg}$ BB, $200 \mathrm{mg} / \mathrm{kg}$, dan 400 $\mathrm{mg} / \mathrm{kg} \mathrm{BB}$. 


\section{Dosis konversi ke hewan uji}

Pemberian dosis fraksi daun sirsak (Annona muricata L.) $100 \mathrm{mg} / \mathrm{kg}$ BB, $200 \mathrm{mg} / \mathrm{kg}$ BB dan $400 \mathrm{mg} / \mathrm{kg}$ BB berdasarlan hasil konversi dosis sediaan obat ke hewan uji tikus yang didasarkan pada berat badan yang digunakan untuk penelitian. Kelompok perlakuan ekstrak bunga wijaya kusuma $100 \mathrm{mg} / \mathrm{kg}$ BB mendapat dosis konversi 7,5 mg/75 g $\mathrm{BB}$, perlakuan ekstrak bunga wijaya kusuma $200 \mathrm{mg} / \mathrm{kg}$ BB mendapat dosis konversi $15 \mathrm{mg} / 75 \mathrm{~g}$ BB dan perlakuan ekstrak bunga wijaya kusuma 400 $\mathrm{mg} / \mathrm{kg}$ BB mendapat dosis konversi 30 $\mathrm{mg} / 75 \mathrm{~g}$ BB. Untuk kosntrol positif dengan allopurinol $10 \mathrm{mg} / \mathrm{kg} \quad \mathrm{BB}$ mendapat dosis konversi $0,75 \mathrm{mg} / 75 \mathrm{~g}$ BB. Dosis yang telah ditentukan kemudian diencerkan dengan akuades sebanyak 1,0 ml. Dosis pemberian allopurinol dan ekstrak bunga wijaya kusuma disesuaikan dengan berat badan setelah tikus dibuat asam urat.

\section{Pengambilan darah dan penetapan}

\section{kadar asam urat}

Hewan uji diambil darahnya dari aorta jantung yang sebelumnya telah dibius, kemudian darahnya diambil melalui aorta jantung sebanyak $\pm 1 \mathrm{~mL}$, ditampung pada blood tube yang sebelumnya telah diisi EDTA untuk menghindari adanya penggumpalan darah. Kemudian darah dan serum dipisahkan dengan cara disentrifuge selama 15 menit pada kecepatan 3.0003.500 rpm. Plasma yang terpisah diambil dan ditentukan kadar asam uratnya. Untuk pengukuran serapan dengan spektrofotometer terlebih dahulu disiapkan tiga buah tabung. Tabung pertama berisi akuades, tabung kedua berisi standar asam urat, dan tabung ketiga berisi serum uji, pada masingmasing tabung ditambahkan masingmasing pereaksi urea uric acid FS TBHBA.

Kadar asam urat ditetapkan berdasarkan reaksi enzimatik menggunakan reagen uric acid FS TBHBA (2,4,6-tribromo-3hydroxybenzoic acid), dengan cara 40 $\mu \mathrm{L}$ bagian plasma darah ditambahkan $2.000 \mu \mathrm{L}$ monoreagen yang dibuat dengan mencampurkan 4 bagian reagen 1 dan 1 bagian reagen 2. Serum yang telah dicampur homogen dengan pereaksi uric acid FS TBHBA diinkubasi selama 10 menit pada suhu $37^{\circ} \mathrm{C}$. Selanjutnya larutan blanko, standart, dan sampel dibaca absorbansinya dengan menggunakan spektrofotometer pada panjang gelombang $546 \mathrm{~nm}$. 


\section{Analisis Data}

Data hasil penelitian ini dianalisis secara statistik dengan menggunakan uji kolmogorov-smirnov untuk mengetahui apakah suatu variabel normal atau tidak. Jika distribusi data normal dan homogen dengan $\mathrm{p}>0,05$, maka analisis dilanjutkan dengan analisis parametrik metode ANOVA menggunakan program SPSS pada tingkat kepercayaan 95\% dengan hipotesis statistik sebagai berikut : $\mathrm{H}_{0}$ : tidak ada perbedaan bermakna antara nilai persentase penurunan kadar asam urat minimum 1 pasang kelompok uji per satuan waktu, $\mathrm{H}_{1}$ : ada perbedaan bermakna antara nilai persentase penurunan kadar asam urat minimum satu pasang kelompok uji per satuan waktu. Pengambilan keputusan didasarkan atas nilai statistik hitung dan nilai statistik tabel.

\section{HASIL PENELITIAN}

Sebanyak 250 gram serbuk bunga wijaya kusuma (Epiphyllum oxypetalum) diekstraksi dengan cara maserasi menggunakan metanol teknis selama \pm 24 jam. Filtrat yang diperoleh dikumpulkan dan diuapkan dengan menggunakan rotary vacum evaporator. Hasil uapan tersebut diperoleh ekstrak kental metanol yang berwarna hijau kecoklatan sebanyak 27 g.

\section{Uji Penurunan Kadar Asam Urat}

Untuk penelitian asam urat, tikus penelitian yang digunakan disiapkan sesuai dengan kaidah-kaidah pemeliharaan hewan untuk penelitian. Tikus penelitian menunjukkan prilaku normal dengan peningkatan berat badan sebesar 110,375 \pm 9,1807 gram, sehingga layak digunakan untuk penelitian. Tikus memiliki kadar asam urat normal sekitar 1,6 mg/dl - 1,8 $\mathrm{mg} / \mathrm{dl}$, sedangkan kelompok $\mathrm{P}_{1}-\mathrm{P}_{5}$ yang diberikan makanan tinggi purin selama 42 hari, telah mengalami peningkatan asam urat diatas $3,00 \mathrm{mg} / \mathrm{dl}$ yang terlihat sejak hari ke-6 dengan persentase kenaikan diatas $100 \%$. Persentase kenaikan dan penurunan kadar asam urat disajikan pada Tabel 1. 
Tabel 1. Persentase kenaikan dan penurunan rata-rata kadar asam urat

\begin{tabular}{|c|c|c|c|c|}
\hline \multirow[t]{2}{*}{$\begin{array}{c}\text { Kelompok } \\
\text { Perlakuan Tikus }\end{array}$} & \multicolumn{2}{|c|}{$\begin{array}{l}\text { Persentase Kenaikan Kadar As. } \\
\text { Urat rata-rata }(\mathrm{n}=4) \text { hari ke- }(\%)\end{array}$} & \multicolumn{2}{|c|}{$\begin{array}{l}\text { Persentase Penurunan } \\
\text { Kadar As. Urat rata-rata } \\
(\mathrm{n}=4) \text { hari ke- }(\%)\end{array}$} \\
\hline & 6 & 9 & 14 & 18 \\
\hline Normal & 0,00 & 2,46 & 4,73 & 7,7 \\
\hline Hiperurisemia & 173,23 & 191,69 & $* 230,46$ & $* 253,23$ \\
\hline $\begin{array}{lll}\text { Allopurinol } & 10 & \mathrm{mg} / \mathrm{kg} \\
\text { BB } & & \\
\end{array}$ & 140,62 & 295,08 & 26,01 & 70,10 \\
\hline Ekstrak $100 \mathrm{mg} / \mathrm{kg}$ BB & 183,38 & 285,85 & 20,33 & 29,50 \\
\hline Ekstrak $200 \mathrm{mg} / \mathrm{kg}$ BB & 117,23 & 136,92 & 28,90 & 49,93 \\
\hline Ekstrak $400 \mathrm{mg} / \mathrm{kg}$ BB & 135,69 & 234,15 & 35,04 & 63,50 \\
\hline
\end{tabular}

PEMBAHASAN

\section{Ekstraksi Bunga Wijaya Kususma (Epiphyllum oxypetalum)}

Sebanyak 500 gram serbuk bunga wijaya kusuma (Epiphyllum oxypetalum) diekstraksi dengan cara maserasi menggunakan metanol teknis selama \pm 24 jam, kemudian disaring sehingga diperoleh filtrat dan residu, sehingga didapat filtrat seluruhnya sebanyak 10 liter dari 13 liter metanol. Filtrat yang diperoleh dikumpulkan dan diuapkan dengan menggunakan rotary vacum evaporator. Hasil uapan tersebut diperoleh ekstrak kental metanol yang berwarna hijau kehitaman sebanyak 27 gram.

\section{Uji Penurunan Kadar Asam Urat}

Untuk penelitian asam urat, tikus penelitian yang digunakan disiapkan sesuai dengan kaidah-kaidah pemeliharaan hewan untuk penelitian. Berat badan tikus ditimbang tiga kali yaitu: pada awal percobaan, setelah adaptasi selama satu minggu di laboratorium, dan sesudah pemberian pakan tinggi purin berlangsung selama sembilan hari. Tikus penelitian menunjukkan prilaku normal dengan peningkatan berat badan sebesar 110,375 \pm 9,1807 g, sehingga layak digunakan untuk penelitian.

Pembentukan asam urat terjadi melalui jalur oksidasi hipoxanthin dan guanin menjadi xanthin oksidase dan guanase. Kemudian xanthin teroksidasi menjadi asam urat dalam reaksi selanjutnya yang dikatalisis oleh enzim xanthin oksidase (Iswantini D., 2003). Dengan demikian, xanthin oksidase merupakan lokasi essensial untuk intervensi farmakologis pada penderita asam urat (Murray dkk, 1996).

Pada hari ke-6 dan hari ke-9 diambil darahnya untuk mengetahui persentase kenaikan kadar asam urat 
darahnya. Pada hari ke-10 s/d hari ke18, tikus diberi perlakuan berupa pengobatan dengan allopurinol dosis 10 $\mathrm{mg} / \mathrm{kg}$ BB pada kontrol positif dan ekstrak metanol bunga wijaya kusuma (Epiphyllum oxypetalum) dosis 100 $\mathrm{mg} / \mathrm{kg}$ BB, $200 \mathrm{mg} / \mathrm{kg}$ BB, dan 400 $\mathrm{mg} / \mathrm{kg}$ BB pada perlakuan kelompok $\mathrm{P}_{3}$ - $\mathrm{P}_{5}$ secara peroral dengan sonde. Hari ke-14 dan hari ke-18 kembali diambil darahnya untuk mengetahui persentase penurunan kadar asam urat darah.

Penetapan kadar asam urat ditentukan dengan metode enzimatik menggunakan reagen uric acid FSTBHBA (2,4,6-tribromo-3 hydroxybenzoic acid) dengan menggunakan alat spektrofotometer UV-Vis. Mekanisme yang terjadi adalah asam urat dioksidasi oleh enzim urikase dengan bantuan $\mathrm{H}_{2} \mathrm{O}$ dan $\mathrm{O}_{2}$ menjadi allantoin, $\mathrm{CO}_{2}$ dan $\mathrm{H}_{2} \mathrm{O}_{2}$ (Kurniastuty A., 2003). $\mathrm{H}_{2} \mathrm{O}_{2}$ yang terbentuk akan bereaksi dengan 4-amino antipirin dan FS-TBHBA (2,4,6-tribromo-3 hydroxybenzoic acid) menjadi kuinonimin yang berwarna merah muda, reaksi tersebut dikatalisis oleh enzim peroksidase (POD).

Tikus memiliki kadar asam urat normal sekitar $1,6 \mathrm{mg} / \mathrm{dl}-1,8 \mathrm{mg} / \mathrm{dl}$, sedangkan kelompok $\mathrm{P}_{1}-\mathrm{P}_{5}$ yang diberikan makanan tinggi purin selama sembilan hari, setelah mengalami peningkatan asam urat diatas $3,00 \mathrm{mg} / \mathrm{dl}$ yang terlihat sejak hari ke-6 dengan kenaikan persentase diatas $100 \%$. Pada kontrol positif $\left(\mathrm{P}_{2}\right)$ dengan pemberian allopurinol dosis $10 \mathrm{mg} / \mathrm{kg}$ BB terjadi penurunan kadar asam urat selama 9 hari pada hari ke-18 sebesar 70,10\%, sedangkan untuk kelompok pemberian $100 \mathrm{mg} / \mathrm{kg}$ BB ekstrak methanol bunga wijaya kusuma (Epiphyllum oxypetalum) terjadi penurunan kadar asam urat sebesar $29,50 \%$, dosis 200 $\mathrm{mg} / \mathrm{kg}$ BB memperlihatkan penurunan asam urat yang lebih signifikan sebesar 49,93\%, sedangkan dosis $400 \mathrm{mg} / \mathrm{kg} \mathrm{BB}$ memberikan efek penurunan kadar asam urat sebesar 63,50\%.

Hasil kadar asam urat yang diperoleh, kemudian dilakukan uji dengan SPSS 16. Uji ini diawali dengan uji kolmogorov-smirnov. Data diketahui terdistribusi normal, dengan $\mathrm{p}>0,05$ dan taraf kepercayaan 95\%. Hasil uji ANOVA menunjukkan nilai $\mathrm{p}<0,05$ sehingga $\mathrm{H}_{\mathrm{a}}$ diterima, artinya terdapat perbedaan bermakna antara penurunan kadar asam urat pada hari ke-14 dan hari ke-18 antara kelompok hiperurisemia dengan kontrol positif dan kelompok perlakuan $100 \mathrm{mg} / \mathrm{kg}$ BB, $200 \mathrm{mg} / \mathrm{kg}$ BB, dan 400 mg/kg BB. 
Hasil uji Tukey/ HSD menunjukkan bahwa perbedaan persentase penurunan kadar asam urat yang bermakna pada hari ke-14 dan hari ke-18, pada kontrol positif dan kelompok perlakuan dan 400 mg/kg BB, dengan nilai perbedaan paling signifikan adalah kelompok perlakuan $400 \mathrm{mg} / \mathrm{kg}$ BB. Hal ini menunjukkan bahwa pemberian ekstrak methanol bunga wijaya kusuma (Epiphyllum oxypetalum) dosis $400 \mathrm{mg} / \mathrm{kg} \quad \mathrm{BB}$ memiliki aktivitas dalam menurunkan kadar asam urat pada hewan uji lebih signifikan. Penetapan dosis yang dapat memberikan penurunan asam urat sebesar $50 \%\left(\mathrm{ED}_{50}\right)$ dilakukan dengan uji probit. Data hasil uji probit diperoleh nilai $\mathrm{ED}_{50}$ ekstrak methanol bunga wijaya kusuma (Epiphyllum oxypetalum) sebesar $221 \mathrm{mg} / \mathrm{Kg} \mathrm{BB}$.

\section{SIMPULAN}

Berdasarkan hasil penelitian yang telah dilaksanakan dapat disimpulkan bahwa:

1. Hasil uji secara in vivo, ekstrak metanol bunga wijaya kusuma (Epiphyllum oxypetalum) dosis $100 \mathrm{mg} / \mathrm{kg} \mathrm{BB}, 200 \mathrm{mg} / \mathrm{kg} \mathrm{BB}$, dan $400 \mathrm{mg} / \mathrm{kg}$ BB mampu menurunkan kadar asam urat, dengan persentase penurunan terbesar adalah dosis $400 \mathrm{mg} / \mathrm{kg}$

BB sebesar 63,50\%.

2. Hasil uji probit diperoleh nilai $\mathrm{ED}_{50}$ ekstrak methanol bunga wijaya kusuma (Epiphyllum oxypetalum) sebesar $221 \mathrm{mg} / \mathrm{Kg}$ $\mathrm{BB}$

\section{SARAN}

Saran yang dapat disampaikan pada penelitian ini adalah :

1. Perlu dilakukan penelitian lebih lanjut dengan mengukur aktivitas dari enzim xanthin oksidase untuk mengetahui mekanisme dari penurunan asam urat dalam darah.

2. Perlu dilakukan penelitian lebih lanjut dengan pemeriksaan histopatologi pada organ ginjal tikus penelitian untuk kontrol normal, hiperurisemia, kontrol positif, dan kelompok perlakuan sehingga diketahui perbedaan pengaruh asam urat terhadap gambaran histopatologi ginjal pada tikus wistar hasil penelitian. 


\section{DAFTAR PUSTAKA}

Asaidi M., 2010, Waspadai Asam Urat, Diva Press, Yogyakarta.

Gaw et al., 1998, Allopurinol Sebagai Inhibitor Spesifik dari Enzim Xanthine Okxidase (XO) yang Mengkatalisis Oksidasi Hypoxanthine menjadi Xanthine dan Asam Urat, Skripsi, Universitas Diponogoro, Semarang.

Iswantini D, Darusman LK., 2003, Effect of Sidaguri Extract as an Uric Acid Lowering Agent On the Activity of Xanthine Oxidase Enzyme, Proceedings of International Symposium On Biomedicines, Biopharmaca Research, Bogor Agricultural University.
Kurniastuty A., 2003, Pengaruh Pemberian Fraksi Etil Asetat Estrak Etanol 70\% Herba Meniran (Phyllantus niruri L.) Terhadap Penurunan Kadar Asam Urat Mencit Putih Jantan Galur Balb-C Hiperurisemia, Skripsi, Universitas Muhammadiyah, Surakarta.

Murray et al, 1996, Biokimia Harper, Edisi 24, diterjemahkan oleh Hartono, A., Buku Kedokteran EGC, Jakarta.

Saraswati, 2009, Diet Sehat Untuk penyakit Asam Urat, Diabetes, Hipertensi, dan Stroke, Yogyakarta, A+Plus Books.

Styer, Larasati, 2000, Buku Ajar Fisiologi Kedokteran. Edisi ke-17. Jakarta: Penerbit Buku Kedokteran EGC.

Tjay, T.H., dan Raharja., 2002, ObatObat penting, Khasiat, Penggunaan dan Efek-Efek sampingnya, Edisi V, Cetakan ke-2, Penerbit PT. Eleks Media Komputindo Kelompok Gramedia, Jakarta. 